\title{
STRATEGI BERADAPTASI UNTUK MAHASISWA PERANTAUAN TERHADAP LINGKUNGAN BARU
}

\author{
M. Aditya Aldiansyah \\ Mahasiswa Prodi Pendidikan Sosiologi, Fakultas Ilmu Sosial \\ Universitas Negeri Padang \\ Rizkaditya2014@gmail.com
}

\begin{abstract}
Overseas students as newcomers to their new environtmet are required to be able to adapt with the environment of the new community around them. This study aims to reveal the adaptation strategies that must be carried out by overseas students. This research uses several theories gathered from the results of previous studies and uses a qualitative approach. Data collection techniques used in the form of library research. This studi result that students must maintain mutual relations with their family, students must be able to understand the language in their area, and student mus be open and accept different cultures.
\end{abstract}

Keywords: strategies, adaptation, overseas students

\begin{abstract}
Abstrak
Mahasiswa perantauan sebagai pendatang baru di lingkungan baru, mereka dituntut untuk mampu beradaptasi dengan lingkungan masyarat baru yang ada di sekitarnya. Artikel ini bertujuan untuk mengungkapkan strategi adaptasi yang harus dilakukan oleh mahasiswa perantauan. Artikel ini menggunakan beberapa teori yang dikumpulkan dari hasil penelitian yang sudah ada sebelumnya dan menggunakan pendekatan kualitatif. Teknik pengumpulan data yang digunakan berupa library research atau studi pustaka. Hasil penelitian ini mengungkapkan bahwa strategi beradaptasi untuk mahasiswa baru dapat disimpulkan bahwa diperlukan pemecahan internal berupa keluarga, yaitu mahasiswa perantau harus menjaga hubungan timbal balik dengan keluarganya, dan pemecahan eksternal berupa bahasa, mahasiswa perantauan harus mampu memahami bahasa di daerah barunya, dan harus memiliki sikap keterbukaan dan menerima segala perbedaan budaya yang ada
\end{abstract}

Kata Kunci: strategi, adaptasi, mahasiswa perantauan

\section{METODOLOGI PENELITIAN}

Pada karya ilmiah ini metode yang saya gunakan adalah studi pustaka atau library research. Studi pustaka library research adalah studi yang digunakan dalam pengumpulan informasi atau data dengan bantuan dari berbagai macam sumber yang telah ada sebelumnya, yaitu seperti jurnal, skripsi, masalah, buku, dokumen, dan sebagainya. Dari berbagai macam sumber yang say abaca, saya menyimpulkan bahwa mahasiswa perantauan banyak menghadapi rintangan dan tantangan baru yang belum pernah ia rasakan sebelumnya. Dari sumber-sumber tersebut, saya juga menjumpai banyak cara atau strategi untuk menghadapi hambatan atau rintanganrintangan tersebut. Mulai dari beradaptasi dengan teman baru yang merupakan orang asli daerah tempat perantauan tersebut, menguasai atau memahami bahasa, berbaur, dan menerima perbedaan yang ada, dan masih banyak lagi. 


\section{PENDAHULUAN}

Manusia sebagai makhluk sosial yang dinamis tentunya akan memaksa mereka untuk memasuki dunia baru yang tentunya memiliki sosial budaya yang mereka kenal sebelumnya sehingga mereka dituntut untuk mampu beradaptasi. Sebagai makhluk sosial juga, manusia tidak luput dari bantuan orang lain yang mana manusia itu sendiri tidak dapat hidup tanpa adanya bantuan atau keterkaitan dengan orang lain. Maka dari itulah manusia dituntut untuk bersosialisasi dan beradaptasi guna meneruskan kehidupan yang lebih baik lagi.

Proses beradaptasi ini tidaklah semudah yang dibayangkan, tentunya pasti ada kendala-kendala atau hambatan-hambatan yang harus dilewati terlebih dahulu. Walaupun demikian, adaptasi sudah kita lakukan pada masa kanak-kanak, di mana keluarga merupakan proses adaptasi yang pertama kali dilakukan oleh manusia. Namun, tentu berbeda tingkatan kesulitan beradaptasi yang dialami oleh masa kanak-kanak dengan masa rempaja. Seperti yang diungkapkan oleh Hurlock (1980) bahwa salah satu tugas pengembangan masa remaja yang paling sulit berhubungan dengan penyesuaian sosial.

Pada masa remaja, umumnya mereka duduk di bangku SMA/SMK, yang mana pergaulan dan proses adaptasinya tidak jauh berbeda dengan lingkun sebelumnya, yaitu pada masa SMP dan juga SD. Hal itu dapat terjadi karena, ruang lingkupnya yang tidak begitu luas, mereka beradaptasi dengan lingkun semasa kecilnya, bukan terhadap lingkungan baru yang menuntut mereka untuk lebih mampu memahami dan mengetahui lingkungan baru tersebut.

Di Indonesia, sebagian besar remaja yang lulus dari sekolah menengah, melanjutkan pendidikannya hingga ke perguruan tinggi (Monks, 2000). Keputusan untuk melanjutkan Pendidikan ke jenjang Pendidikan tinggi sendiri memiliki berbagai alasan. Dari keinginan untuk mengeyam Pendidikan tinggi, memperoleh gelar, menambah pengetahuan, hingga pengembangan diri (Sharma, 2012). Dalam hal ini, tentunya remaja akan melewati masa transisi yang mewajibkan mereka untuk beradaptasi lebih tinggi lagi. Lapsley, Rice, \& Fitz Gerald (1990) mengungkapkan bahwa untuk menewati masa transisi ini dengan baik, dibutuhkan tingkat adaptasi yang tinggi dari remaja. Selaras dengan pernyataan di atas Tinto (1993) mengunhkapkan, kemampuan dalam mengatur dan menyeimbangakan antara kehiudpan sosial dan akademik dapat membantu proses penyesuaian diri pada mahasiswa di lingkungan perguruan tinggi.

Dalam perguruan tinggi, umumnya mahasiswa-mahasiswa tersebut merupakan perantauan dari berbagai macam daerah yang tentunya memiliki sosial budaya dan kebiasaan yang berbeda dari daerah tempat mereka menempuh Pendidikan tinggi tersebut. Sebuah studi oleh Brier dan Paul (2001) merujuk pada aspek friendsickness sebagai sebuah determinan dari penyesuaian diri seseorang di perguruan tinggi. Mereka menggagas hal ini dari studi sebelumnya yang menyatakan bahwa ketika seseorang kehilangan kelompok teman akrab mereka, dan mereka berada pada lingkungan yang tidak akrab, akan muncul perasaan sedih secara emosional dan rasa kehilangan yang mendalam. Para peneliti menyimpulkan 
bahwa semakin erat sebuah kelompok pertemanan, maka semakin sulit pula bagi para anggotanya untuk berubah tanpa teman-teman lama mereka. Hal ini menunjukkan bahwa diantara bagian yang tersulit dari penyesuaian sosial mahasiswa baru adalah meningkatnya pengaruh dari kelompok sebaya dalam perubahan perilaku sosial, pegelompokan sosial yang baru, nilai-nilai yang baru, serta penolakan dari lingkungan sosial yang baru (Nurdin, 2009).

Setiap mahasiswa baru tentunya memiliki harapan atau ekspektasi dalam menempuh pendidikannya. Salah satu harapannya yaitu memiliki teman baru, mampu beradaptasi dan berjalan dengan baik. Namun, realitas yang akan mereka hadapi tidak sesuai dengan ekspektasi mereka, seperti hidup mandiri mengontrak rumah tanpa bantuan orang tua yang tentunya tidak dapat berjalan dengan baik-baik saja. Pada umumnya, orang tua yang memegang peranan terbesar dalam pembentukan sikap dan perilaku ankanya, karena pola asuh orang tuaakan membentuk kebiasaan anak yang secara tidak langsung mempengaruhu pola hidupnya. Balwin (dalam Setiono, 2011) mengatakan individu yang tinggal bersama orang tua mereka akan lebih terkontrol oleh orang tua dengan baik. Beda dengan kehidupan mahasiswa baru yang merantau dan jauh dari orang tua yang tidak dapat membantu dan memberikan saran atau motivasi serta tuntutan secara langsung kepada mereka, sehingga membuat mahasiswa baru tersebut mengalami hambatan atau gangguan dalam menjalani kehidupan barunya termasuk di dalamnya perbedaan sosial budaya. Berdasarkan studi yang dilakukan oleh Zuni Mitasari dan Yuswa Istikomayanti tentang "Studi Penyesuaian Diri Mahasiswa Luar Jawa di Universitas Tribhuwana Tunggadewi Malang" yang melibatkan 79 orang mahasiswa, dan semua mahasiswa yang dilibatkan tersebut mengalami cultural shock, dikarenakan faktor utamanya yaitu adaptasi yang tidak sempurna.

Dalam segala permasalahan yang tertera di atas, membuat saya tertarik untuk membuat artikel tentang adapasi mahasiswa baru yang betujuan agar dapat membantu mahasiswa baru dalam beradaptasi dengan lingkungan barunya. Metodologi yang saya gunakan yaitu library research, sehingga sumber-sumber yang saya dapatkan dari berbagai studi, jurnal, atau hasil penelitian dan pengamatan orang lain yang sudah ada sebelumnya. Oleh karena itu, saya memiliki studi yang relevan terhadap mateir yang akan saya tulis sebagai acuan dan pedoman dalam penulisan.

Studi pertama yaitu penelitian yang dilakukan oleh Marshella Devinta/Nur Hidayah dan Grendi Hendrastomo dalam jurnalnya (2015) yang secara khusus mengulas tentang fenomena cultural shock (gegar budaya) pada mahasiswa perantauan di Yogyakarta. Dalam penelitiannya, mereka menyimpulkan bahwa masa cultural shock akan dialami oleh setiap mahasiswa perantauan yang baru memasuki tahap semester awal perkuliahan hanya saja cultural shock pada setiap individu berbedabeda mengenai sejauh mana cultural shock mempengaruhi hidupnya. Studi kedua yaitu dari penelitian Uthia Estiane (2015) tentang pengaruh dukungan sosial sahabat terhadap penyesuaian sosial mahasiswa baru di lingkungan perguruan tinggi. Dari hasil penelitian dan pengolahan data yang diperoleh disimpulkan bahwa terdapat pengaruh dukungan sosial sahabat terhadap penyesuaian sosial mahasiswa 
di lingkungan perguruan tinggi. Selanjutnya studi yang dilakukan oleh Lia Mareza \& Agung Nugroho (2016), tentang minoritas di tengah mayoritas. Dalam hasil studi mereka, dapat disimpulkan bahwa mahasiswa perantauan memiliki berbagai hambatan dalam kehidupannya di lingkungan baru mereka. Studi relevan yang terakhir adalah pengamatan dan penelitian yang dilakukan oleh Susi Andriani dan Oksiana Jatiningsih (2015) dalam jurnalnya tentang strategi adaptasi sosial siswa Papua di Kota Lamongan yang menyimpulkan bahwa hasil pembahasan yang dikaji dari teori Bennet dapat disimpulkan bahwa siswa Papua menggunakan strategi adaptasi perilaku untuk menghadapi perbedaan yang ada. Berbeda dengan artikel saya, yaitu tentang upaya atau cara agar mahasiswa mampu beradaptasi dengan baik.

Berdasarkan studi relevan yang ada, maka saya akan mengkaji tentang strategi mahasiswa perantauan dalam beradaptasi dengan lingkungan barunya. Dari berbagai masalah yang sudah disebutkan di atas, sehingga muncullah pertanyaan, bagaimanakah cara agar mahasiswa mampu beradaptasi dengan lingkungan barunya?

\section{PEMBAHASAN}

Mahasiswa perantauan tentunya tidak lepas dari berbagai macam permasalahn yang dihadapinya terhadap lingkungan barunya. Dalam proses adaptasi lingkungan baru oleh mahasiswa perantauan diperlukan pemecahan masalah. Pemecahan masalah dalam pembahsan ini ada dua faktor, yauitu faktor internal dan eksternal. Faktor internal yang dimaksud di sini adalah seperti dri mahasiswa tersebut dan hubungannya dengan keluarganya. Sedangan dalam faktor eksternal, yaitu tentang lingkungan barunya, seperti budaya, bahasa, serta teman-teman dan masyarakat baru di lingkungannya tersebut. Dalam hasil penelitian yang dilakukan oleh Devita Cahya Permata dan Ratih Arruum Listiyandini, yang dilakukan secara wawancara oleh dua universitas berbeda untuk menggali berbagai macam permasalahan yang ada para mahasiswa perantauan. Berdasarkan hasil wawancara dapat disimpulkan bahwa mahasiswa tahun pertama yang merantau mengalami kesulitan dalam beradaptasi terhadap lingkungan mereka yang baru serta merasa kesepian akan ketidakhadirannya orang tua. Berhubungan juga dengan studi yang dilakukan oleh Lia Mareza \& Agung Nugroho, tentang homesick (merindukan kampug halaman). Menurut Archer, et all. (1998), dalam studi mereka, homesickness adalah reaksi psikologis dari tidak adanya kehadiran significant others dan lingkungan yang dikenalnya secara akrab. Efek homesickness antara lain kesepian, kesedihan, dan kesulitan mengatur diri mahasiswa di lingkungan universitas. Sebagai mahasiswa perantauan mau tidak mau harus meninggalkan keluarga, sahabat karib, dan temanteman lainnya yang ada di kampung halamannhya dan mulai mencari teman baru sebagai gantinya dalam lingkungan perkuliahannya saaat ini. Dari hasil penelitiannya tersebut, saya sebagai penulis setuju, maka dari itu hubungan timbal balik antara mahasiswa dan keluarga harus tetap terjaga dan terjalin dengan baik. Orang tua juga berperan aktif dalam proses adaptasi anaknya. Orang tua dapat memotivasi atau mendorong serta mengontrol anaknya agar mampu untuk beradaptasi di lingkungan barunya. Kendalanya adalah jarak yang membatasi. Sehingga cara ampuh agar tetap terjalinnya hubungan adalah pulang ke kampung 
halamannya. Namun, bila terlalu jauh, dapat melalui komunikasi jarak jauh melalui telepon genggam. Dalam hasil skirpsi yang dilakukan oleh Endah Mita Ayu Permatasari (2017), yang juga menyarankan untuk berkomunikasi melalui telepon genggam bagi yang jarak kampungnya jauh dari tempat ia menempuh pendidikan tinggi. Namun, tetap juga masih dapat dilakukan dengan pulang mengunjungi kampung halaman saat libur Panjang seperti libur semester. Hal ini guna untuk tetap menjaga silaturahmi dan tetap menciptakan suasana harmonis. Sehingga mahasiswa dalam beradaptasinya mendapatkan dorongan dan kepercayaan diri yang ia dapatkan dari keluarganya karena memiliki hubungan yang erat dan saling beketergantungan. Selanjutnya yaitu dari lingkungan tempat tinggal mahasiswa itu sendiri, seperti tempat kos atau kontrakannya. Dalam hal ini dimasukkan dalam tahap internal karena lingkungan kos atau tempat tinggalnya sudah menjadi bagian dari kehidupannya seperti keluarga. Lingkungan kos dan kampus memiliki proses pebelajaran sosial bagi mahasiswa sehingga mereka harus mengambil keputusan untuk bertahan dan sukses dalam perkuliahan mereka (Hidayat, 2018). Jadi, lingkungan kos juga mempengaruhi kehidupan barunya. Dalam lingkungan keluarganya, tidak ada perbedaan budaya yang signifikan. Sedangkan kos lebih bersifat hetrogen, yang terdiri dari berbagai kalangan mahasiswa dengan budaya yang berbeda dan masyarakat setempat yang langsung menjadi bahagian lingkungan mereka. Artinya proses sosial yang berlangsung di kos telah menjadi bahagian dalam jaringan masyarakat melalui interaksi setiap harinya (Hidayat, 2018) sehingga dalam kehidupan kos mahasiswa juga mampu untuk beradaptasi dengan lingkungan barunya dengan teman-teman kosnya yang berbeda budaya juga sehingga lebih memudahkan berinteraksi dengan lingkungan barunya dengan saling belajar dan memahami budaya di lingkungan baru mereka..

Setelah melewati masalah internal dalam keluarga seperti yang dijelaskan sebelumnya, mahasiswa juga harus mampu untuk menyesaikan permasalahan eksternal atau masalah yang ada di luar diri mahasiswa tersebut dalam dunia barunya. Dalam studi Lia Mareza \& Agung Nugroho, menyatakan bahwa Mahasiswa asing dan luar Jawa memilih cara beradaptasi sesuai kebutuhan dan keinginan, pilihannya adalah meleburkan diri dengan orang-orang dan kebudayaan setempat. Salah satunya adalah akomodasi Bahasa, makanan, dan agama. Seperti yang kita keatahui, bahwa budaya antar daerah tentunya berbeda, sehingga hal ini dapat dijadikan sebagai hambatan dalam beradaptasi bagi mahasiswa perantauan. Salah satu perbedaan budaya yang dapat dirasakan secara signifikan yaitu perbedaan bahasa. Menurut Giles, Coupland, dan Coupland (1991:7), dalam (Mareza L. 2016) perbedaan bahasa dapat berupa utterance length, posture, gesture, head nodding and facial affect, self disclosure, vocal intencity, information density, pausing frequencies, and length. Menurut Ruben, dalam Mulyana, 2003:141 (Mareza L. 2016) komunikasi persona dianggap sebagai merasakan, memahami, dan berperilaku terhadap objek-objek dan orang-orang suatu lingkungan dan menjadi proses yang dilakukan individu untuk menyesuaikan diri dengan lingkungannya. Sehingga pemahaman bahasa di lingungan baru setidaknya mahasiswa harus mampu atau memahaminya agar mudah dalam berkomunikasi dan berbaur guna memudahkan proses adaptasi itu sendiri. Salah satu cara agar mampu memahami Bahasa yang berbeda tersebut, yaitu dengan meniru logat Bahasa itu 
seperti yang dilakukan oleh mahasiswa Papua yang berada di lingkungan Jawa, seperti hasil studi dari Susi Adriani dan Oksiana Jatiningsih. Dalam meniru logat bahasanya saja, sudah dapat memudahkan kita untuk memahami arti dari Bahasa tersebut dengan mudah. Dengan memahami bahasa daerah baru mahasiswa tersebut ampu membuat silaturahmi dan dapat berhubungan baik dengan masyarakat dan teman-teman barunya di daerah tersebut, sehingga menciptakan suasana saling pengertian dan memahami satu sama lainnya akan perbedaan bahasa, budaya, serta nilai dan norma yang ada.

Strategi terakhir agar mahasiswa mampu beradaptasi dengan lingkungan barunya, adalah dengan menciptakan sikap keterbukaan dan menerima segala perbedaan budaya yang ada agar tidak terciptanya sikap etnosentrisme atau yang biasanya disebut merendahkan dan menjelekkan budaya lain. Tentunya apabila hal ini terjadi, pasti akan terjadinya konflik dan menjadikan mahasiswa tersebut menjadi lebih sulit lagi dalam berdaptasi. Seperti yang kita ketahui bahwa Indonesia terdiri dari berbagai macam suku bangsa, dan agar terciptanya suasana rukun tentu saja sikap keterbukaan dan saling menerima budaya lain akan tetap menjaga keutuhannya, begitu pula dalam menjalankan kehidupan sebagai mahasiswa perantauan. Berhubungan dengan studi yang dilakukan oleh Rahaditya Puspa Kirana (2012) tentang strategi adaptasi pekerja Jepang yang bekerja di Indonesia. Seperti yang kita ketahui, bahwa budaya Jepang dan budaya yang ada di Indonesia tentu saja sangat berbeda, sepeerti norma adat, norma kesopanan, dan lain sebagainya meskipun sama-sama terletak di Kawasan Asia. Dalam hasil penelitiannya, dapat disimpulkan bahwa pekerja Jepang tersebut melakukan persiapan terlebih dahulu sebelum beraktivitas, melakukan hal-hal yang merupakan kegemaran, bersikap terbuka, dan membiasakan diri dengan kebiasaan orang Indonesia. Rahaditya juga menegaskan beberapa faktor-faktor yang dapat mendukung dalam proses adaptasi pekerja Jepang tersebut, yaitu sifat yang terbuka dan fleksibel untuk dapat mengerti dan menerima budaya dan kebiasaan di tempat yang baru. Bahwa, pekerja Jepang tersebut menerima dan mengakui budaya yang ada, dan menganggap perbedaan yang ada di Indonesia dan dari Negerinya sendiri itu wajar saja terjadi tergantung cara seseorang untuk menyikapi hal tersebut. Dari studi tersebut, saya menerima hasil studinya dan menyimpulkan bahwa sebagai mahasiswa perantauan dapat meniru pekerja Jepang tersebut seperti melakukan persiapan, dalam hal ini persiapan yang dimaksud adalah kita harus mengenal terlebih dahulu bagaimana budaya dan kebiasaan yang ada di lingkungan baru kita tersebut. Tahap persiapan ini dapat kita lakukan dengan cara mencari tahu melalui media massa atau internet. Bisa juga dengan teman-teman sepergaulan yang berasal dari daerah tersebut. Lalu, kita juga harus memiliki sikap terbuka seperti yang telah dikatakan sebelumnya dan juga harus fleksibel, sehingga terciptanya nuansa saling menghargai antar satu budaya dengan budaya lain tersebut. Dengan mengikuti berbagai strategi di atas dengan baik dan benar, dapat menciptakan suasana kehidupan sebagai mahasiswa perantauan merasa baik-baik saja dan sudah siap untuk menerima perbedaan yang ada dan tidak adanya gangguan dalam menjalankan kehidupan barunya sebagai mahasiswa. 


\section{PENUTUP}

Mahasiswa perantauan memiliki hambatan dan rintangan yang lebih besar daripada mahasiswa bukan perantauan. Oleh karena itu, mereka harus mampu beradaptasi dengan cara tetap menjaga silaturahmi dengan keluarga, berbaur dengan teman di daerah tersebut sehingga dapat memahami bahasa mereka, dan mahasiswa perantauan juga harus bersikap terbuka dan menerima semua perbedaan yang ada. Saya menyarankan kepada penulis berikutnya untuk mengkaji hal yang menarik yang ada di artikel ini. Namun tidak dapat dikembangkan dikarenakan di luar dari tujuan penelitian tersebut, yaitu memaparkan tentang strategi adaptasi yang dikemukakan oleh Bennet.

\section{DAFTAR PUSTAKA}

Andriani, S., \& Jatiningsih, O. (2015). Strategi Adaptasi Sosial Siswa Papua di Kota Lamongan. Kajian Moral dan Kewarganegaraan, 2(3), 530-544

Devinta, M. (2016). Fenomena cultural shock (gegar budaya) pada mahasiswa perantauan di Yogyakarta. E-Societas, 5(3)

Estiane, U. (2015). Pengaruh dukungan sosial sahabat terhadap penyesuaian sosial mahasiswa baru di lingkungan perguruan tinggi. Jurnal Psikologi Klinis dan Kesehatan Mental, 4(1), 29-40

Mareza, L., \& Nugroho, A. (2016). MINORITAS DITENGAH MAYORITAS (STRATEGI ADAPTASI SOSIAL BUDAYA MAHASISWA ASING DAN MAHASISWA LUAR JAWA DI UMP). SOSIOHUMANIORA: Jurnal Ilmiah Ilmu Sosial dan Humaniora, 2(2)

Hidayat, M. (2018). STUDI PENGARUH KEMANDIRIAN MAHASISWA YOGYAKARTA TERHADAP PERSTASI AKADEMIK: RESPON 60 MAHASISWAWI DI YOGYAKARTA. SOCIUS, 4(2), 109-119. 